\title{
De ruimtetoerist : vragen over technologie en toekomst
}

Citation for published version (APA):

van Lente, H. (2015). De ruimtetoerist : vragen over technologie en toekomst. Maastricht University. https://doi.org/10.26481/spe.20150918hl

Document status and date:

Published: 18/09/2015

DOI:

10.26481/spe.20150918hl

Document Version:

Publisher's PDF, also known as Version of record

\section{Please check the document version of this publication:}

- A submitted manuscript is the version of the article upon submission and before peer-review. There can be important differences between the submitted version and the official published version of record.

People interested in the research are advised to contact the author for the final version of the publication, or visit the DOI to the publisher's website.

- The final author version and the galley proof are versions of the publication after peer review.

- The final published version features the final layout of the paper including the volume, issue and page numbers.

Link to publication

\footnotetext{
General rights rights.

- You may freely distribute the URL identifying the publication in the public portal. please follow below link for the End User Agreement:

www.umlib.nl/taverne-license

Take down policy

If you believe that this document breaches copyright please contact us at:

repository@maastrichtuniversity.nl

providing details and we will investigate your claim.
}

Copyright and moral rights for the publications made accessible in the public portal are retained by the authors and/or other copyright owners and it is a condition of accessing publications that users recognise and abide by the legal requirements associated with these

- Users may download and print one copy of any publication from the public portal for the purpose of private study or research.

- You may not further distribute the material or use it for any profit-making activity or commercial gain

If the publication is distributed under the terms of Article $25 \mathrm{fa}$ of the Dutch Copyright Act, indicated by the "Taverne" license above, 
Prof. dr. ir. Harro van Lente

Faculteit der Cultuur- en Maatschappijwetenschappen

\section{De ruimtetoerist - vragen over technologie en toekomst}


De ruimtetoerist - vragen over technologie en toekomst 
All rights reserved. No part of this publication may be reproduced, modified, stored in a retrieval system or made public without the prior written permission of the author or publisher. 


\section{De ruimtetoerist - vragen over technologie en toekomst}

Rede

Uitgesproken bij aanvaarding van de leerstoel

Science and Technology Studies

Maastricht, 18-09-2015

door Prof. dr. ir. Harro van Lente 
Geachte rector magnificus, geachte aanwezigen,

\section{Inleiding}

"Ga je ook emigreren?" Dat vroegen vrienden en collega's in Utrecht toen ik ze blij vertelde dat ik een hoogleraarspositie in Maastricht had aanvaard. Naast de ironische flirt met Randstadcentrisme, spreekt uit deze grappige vraag ook het andere van Maastricht en van Limburg. Vaak wordt er in één adem aan toegevoegd, soms jaloers, soms troostend, dat Maastricht wel een mooie stad is en het heuvelland prachtig. Maastricht, zo blijkt, is anders - in taal, in ritme, in sociale verhoudingen - én aantrekkelijk voor een toeristisch bezoek. Randstedelingen gaan naar Maastricht als toerist voor een ontmoeting met het andere, voor ontspanning en nieuwsgierigheid.

Er zijn vele soorten toeristen, zoals $u$ weet. De meesten komen alleen op bepaalde plaatsen en niet op andere. $\mathrm{Er}$ is een zorgvuldige begeleiding van de nieuwsgierigheid. Ze worden geleid naar het Vrijthof, Wyck en de Servaasbrug, maar niet naar het industrieterrein van Gronsveld of het woonwagenkamp in Amby. Hier is wat John Urry (1990) noemt de 'tourist gaze' werkzaam, de blik van de toerist. De blik van de toerist ziet de wereld volgens de sjabloon van wat de toerist geacht wordt aan te treffen. Met de blik van de toerist wordt het vreemde onschadelijk gemaakt, getemd, geannexeerd, door het in te passen in de sjabloon van wat de toerist geacht wordt te zien. Toeristische plaatsen versterken dit door zich te voegen naar wat zij denken dat toeristen verwachten aan te treffen. Door deze terugkoppeling ontmoet de toerist dus niet zozeer het andere maar het resultaat van het collectieve verbeeldingsproces van toerismegevers en toerismenemers (Bolton, 2002). Maar niet alle toeristen zijn zo - er zijn er ook die buiten de gebaande paden gaan en zaken ontdekken die anderen ontgaat, en zelfs de bewoners van de stad ontgaan. Door hun positie als bezoeker en hun ervaringen met andere 
plaatsen zijn ze in staat om van een afstand te kijken, te vergelijken en patronen te zien.

Toerisme is, zoals u weet, één van de grootste bedrijfstakken ter wereld met een omzet van honderden miljarden euro's. Vanmiddag zal ik het verschijnsel toerisme op twee manieren gebruiken: als voorbeeld van hoe je technologische ontwikkelingen kan bekijken en begrijpen en als metafoor voor het vakgebied waar ik werkzaam ben, het vakgebied van wetenschap- en techniekonderzoek, Science and Technology Studies, afgekort STS.

\section{Ruimtetoerisme}

Er zijn meer instanties met de afkorting STS. Zo is er een Space Tourism Society, gericht op het ontwikkelen van technologieën en mogelijkheden voor ruimtetoerisme. Dit is het voorbeeld dat ik wil bespreken. Ruimtetoerisme is een op dit moment plaatsvindende innovatie, waarin alle dynamieken van innovatie te zien zijn en waar vanuit STSers, door hun perspectief, belangrijke vragen kunnen stellen. Ik zal laten zien welke dromen, ambities en krachten hier werkzaam zijn en zal daarna bespreken hoe ik een geval als dit vanuit mijn vakgebied wil onderzoeken en bevragen.

Lang heeft de ruimtevaart in het teken gestaan van de koude oorlog en de wapenwedloop. De lancering van de Sputnik door de Russen in 1957 gaf een schok die leidde tot het grote Amerikaanse project om een man op de maan te zetten, hetgeen, zoals u weet, ook is gebeurd in 1969. 'Putting a man on the moon' is sindsdien een icoon geworden voor het succesvol mobiliseren van wetenschap en technologie. Het in de ruimte brengen van mensen is echter uiterst kostbaar en complex en langzamerhand zijn onbemande vluchten ook steeds gebruikelijker geworden.

Sinds de jaren tachtig zijn er ook enkele burgers de ruimte in gegaan, zoals een Amerikaanse senator in 1985 en een Amerikaans parlementslid in 1986. Zij vlogen mee met de 
ruimteveer Challenger. Dit had geen technische noodzaak en werd vooral gezien als een publiciteitsactie van NASA om op de politieke agenda te blijven. Maar de idee dat ook anderen dan getrainde astronauten de ruimte in zouden kunnen bestaat al langer - een fantasie die wordt gevoed door uitgebreide science-fiction literatuur, met schrijvers als Isaac Asimov en Arthur C. Clarke en door de populariteit van films als 2001 a Space Odyssee. Jules Verne schreef al over reizen naar de maan en ook Kuifje en kapitein Haddock zijn er al geweest.

Vanaf de jaren negentig van de vorige eeuw wordt er door ruimtevaartorganisaties marktonderzoek gedaan naar de mogelijkheid van ruimtetoerisme. Door het einde van de koude oorlog is de financiering van ruimtevaart problematischer geworden en ruimtetoerisme kan wellicht een nieuwe inkomstenbron zijn. De ontwikkelaars van het aanbod staan voor het bekende kip-en-ei probleem van nieuwe technologie. Zonder betalende klanten kan het ruimtetoerisme niet van de grond komen, maar er zullen pas klanten komen indien de prijs beduidend lager is dan de huidige kostprijs. Die prijs kan pas zakken met schaalvoordelen, de 'economies of scale'. Het is een klassiek innovatiedilemma: zonder klanten geen technologie, zonder technologie geen klanten. Hoe de 'price gap' te overwinnen?

Een marktonderzoek uit 1996, dus bijna twintig jaar geleden, toont de resultaten van een survey in 3 landen: Japan, Duitsland en de VS (Abitzsch 1996). Het laat zien dat een groot deel van de bevolking geïnteresseerd is in ruimtetoerisme en is ook nog bereid er flink voor te betalen, tot aan een heel jaarsalaris (Abitzsch 1996). De resultaten verschillen overigens per land en de onderzoekers laten zich verleiden tot allerlei speculaties hierover. Zo verklaren ze de geringere interesse voor ruimtetoerisme van Duitse ondervraagden vraag naar als volgt: "Maybe a reason for that lies in the more prosaic German lifestyle. " (Abitzsch 1996, p.3). Een ondernemende wereldburger wordt kennelijk geacht wel de ruimte in te willen en als je dat niet wil ben je 'prosaic', suf en saai. En wat wil men dan doen in de ruimte? Het 
overgrote deel wil vooral kijken. Mooi zo, concludeert de marktstudie: dit betekent dat er vooral ramen in het ruimtetoestel moeten zitten, veel meer is niet nodig. Waarom zou men eventueel niet de ruimte in willen? Amerikanen zijn vooral bezorgd over de veiligheid, Duitsers over de milieuaspecten. Al met al, zo is de conclusie, is er voldoende potentie voor een betalende markt. Een ruimtevlucht moet dan te maken zijn voor zo'n $\$ 50.000$. Voor hetzelfde bedrag, zo meldt het rapport verder, kan de vlucht worden verlengd met een verblijf in een ruimtehotel. In de eerste fase van de ontwikkeling van ruimtetoerisme zal het gaan om dagtrips, voor de zeer rijke klanten. Na een aantal jaren, als de kosten substantieel gedaald zullen zijn, wordt het betaalbaar voor een wat grotere groep. Daarna wordt het veel goedkoper en is het bereikbaar voor een massamarkt. Voor degene die zich toch willen onderscheiden is het dan goed om een ruimtehotel te maken. Deze stapsgewijze strategie voorkomt vroegtijdige verzadiging van de markt, zo meldt het onderzoek (Abitzsch 1996, p.11). Het rapport voorspelt een spoedig begin van de ontwikkeling.

\section{Vrije val}

Bij ruimtetoerisme wordt een onderscheid gemaakt tussen 'orbitale' en 'suborbitale' ruimtevluchten. Bij de laatste bereikt het ruimtevaartuig een hoogte van ongeveer 100 km, de zogenaamde Kármánlijn die een denkbeeldige en vrij willekeurig getrokken grens trekt tussen lucht- en ruimtevaart, en keert dan na een paar minuten weer terug. Deze hoogte is voldoende om de kromming van de aarde te kunnen zien. De zwaartekracht is op $100 \mathrm{~km}$ hoogte trouwens bijna net zo groot als op aarde, slechts zo'n 3\% minder. Maar bij de ruimte hoort gewichtloosheid, hoe moet je dat dan bieden? Het is mogelijk om bij de terugkeer gewichtloosheid te ervaren wanneer de snelheid even groot is als de valsnelheid. Vrije-val toerisme dus. Bij orbitale vluchten is het verblijf buiten de dampkring langer en wordt de aarde één of meerdere malen omcirkeld in een ruimteverblijf. Dennis Tito, die bekend staat als de eerste 
ruimtetoerist, heeft dit gedaan in 2002 aan boord van het internationale ruimtestation ISS, dat op $350 \mathrm{~km}$ hoogte om de aarde cirkelt. Het kostte hem 20 miljoen dollar. Na hem zijn er nog zes gevolg, maar in 2009 heeft het ruimtestation de poorten gesloten voor bezoekers. Het werd te vol en te druk.

De kortere en minder hoge suborbitale vluchten zijn sindsdien steeds meer in de aandacht gekomen. Op de website iExplore, waar vakanties en toeristische bestemmingen worden besproken en samengebracht in allerlei categorieën, is er ook een lemma over 'space travel', tussen andere soorten activiteiten die je mogelijk zou willen ondernemen, zoals wandelen of duiken. Je kunt er lezen over de voorbereidingen en je krijgt handige tips over wat je mee kunt nemen. Breng niet teveel mee, lezen we, want het is niet ruim aan boord en let ook vooral op de aanwijzingen van het lanceerstation. Veel wijzer wordt je er niet van, maar het opvallende is dat de optie wordt besproken alsof het een bestaande mogelijkheid is waarvoor je binnenkort reeds zou kunnen vertrekken.

Dat kan niet. Bij sommige aanbieder kun je wel reeds boeken. In zijn boek Tourists in Space: a Practical Guide bespreekt Erik Seedhouse (2008) negen aanbieders van ruimtereizen. Vooral het Virgin Galactic is spraakmakend. De oprichter en leider is Sir Richard Branson, die ook eerder met het merk Virgin de muziekindustrie en de luchtvaartindustrie heeft veranderd. Hij wordt gezien als een inspirator en een visionair, als iemand die breder en verder kijkt dan de doorsnee CEO. Op de website van Virgin Galactic wordt het zo geformuleerd:

Since the dawn of the space age, only 549 humans have traveled above the Earth's atmosphere and into space. [...] most of our planet's seven billion people have had no opportunity to experience space and all of its possibilities for themselves, regardless of their passion or talents. Virgin Galactic is changing that. Our purpose is to become the spaceline for 
Earth; democratizing access to space for the benefit of life on Earth.

Virgin Galactic is dus niet zozeer bezig met een commerciële activiteit, maar met een project voor het heil van de mensheid: democratisering van de ruimtereizen voor de zeven miljard die er nog niet zijn geweest (best veel inderdaad), "for the benefit of life on Earth". Vergelijkbare vergezichten horen van Elon Musk, de ondernemer die miljarden verdiende in Silicon Valley, die niet alleen de hoofdsponsor van de elektrische autofabrikant Tesla is, maar ook oprichter van SpaceX. Het doel van SpaceX is "enabling people to live on other planets" en Elon Musk ziet de ontwikkeling van ruimtetoerisme als een verzekeringspolis (Verhovek, 2014).. Mocht het immers niet lukken op aarde dan hebben we in ieder geval nog meer opties. Ons bestaan moet 'multiplanetary' worden, enkelplanetig denken is bekrompen. Vergelijkbare gedachten horen we bij het spraakmakende project MarsOne, dat als doel heeft om een aantal mensen op Mars te laten wonen binnen een aantal decennia. Vrijwilligers voor een enkeltje Mars konden zich melden en dit leidde tot 200.000 aanmeldingen. Met ruimtetoerisme heeft het niet zoveel te maken, maar wel met de aloude fascinatie dat ons lot toch wellicht niet onlosmakelijk verbonden is met het lot van de planeet Aarde.

Vorig jaar is op 31 oktober een testvlucht van Virgin Galactic geëindigd in een tragedie. $\mathrm{Na}$ de lancering ontplofte het ruimtevoertuig SpaceShipTwo, het verongelukte in de Mojave woestijn in Californië. De piloot raakte zwaargewond en de co-piloot verongelukte. Naar aanleiding van dit ongeluk is er een korte maar felle discussie geweest over nut en noodzaak van ruimtetoerisme. Het is gevaarlijk, het is alleen voor de happy few, het is vervuilend en het dient nergens voor, zo redeneerden de tegenstanders. Voorstanders van verdere ontwikkeling van ruimtetoerisme wijzen op het belang van technologische ontwikkeling en het brengen van offers. Vaak wordt hierbij vergeleken met de pioniers van de luchtvaart. Ook toen vielen ook er doden, 
was er scepsis, afkeuring en ongeloof. Deze zwartkijkerij heeft ongelijk gekregen, zo stellen voorstanders. Het is belangrijk voor de mensheid om door te gaan, ook als dat offers vraagt. Het gaat bij die argumentatie dan nauwelijks meer over toerisme, het gaat om vooruitgang en om de kracht van ambitie en verlangen. Voor de voorstanders zijn de eerste toeristen geen buitenissige miljardairs, maar wegbereiders, zoals de eerste bezitters van een auto de wereld mobiel hebben gemaakt en de kopers van de eerste peperdure computers de internetrevolutie mogelijk hebben gemaakt. Niet iedereen gaat mee in deze visionaire bejubeling. Time Magazine bijvoorbeeld, oordeelde hard en sprak over onvergeeflijke hoogmoed in een redactioneel commentaar (Kluger 2014). Richard Branson is dan geen visionair meer, maar een overmoedige waaghals die levens op het spel zet met speeltjes voor de verwende en verveelde allerrijksten

"A fatal accident in the Mojave Desert is a lesson in the perils of space hubris. It's hard not to be angry, even disgusted, with Branson himself. He is, as today's tragedy shows, a man driven by too much hubris, too much hucksterism and too little knowledge of the head-crackingly complex business of engineering. For the 21st century billionaire, space travel is what buying a professional sports team was for the rich boys of an earlier era: the biggest, coolest, most impressive toy imaginable."

\section{Dynamiek van innovatie}

Aan de hand van het voorbeeld van ruimtetoerisme wil ik laten zien met welke vragen over technologie en toekomst ik de komende jaren aan de slag wil en hoe daarmee meer zicht ontstaat op de ontwikkeling van nieuwe technologie. Het geval illustreert meerdere aspecten van mijn STS benadering. Zo geeft het zicht op de dynamiek van innovatie en de activiteiten van netwerkbouwers. We zien figuren als Richard Branson met hun visies en hun publieke 
zichtbaarheid. Ik wees al op het centrale dilemma van netwerkbouwers: hoe een vraag te krijgen terwijl er nog geen aanbod is. Het is niet zo dat het aanbod aan ruimtereizen de vraag volgt (er is nog helemaal geen vraag), het is ook niet zo dat de vraag het aanbod volgt (er is nog helemaal geen aanbod). Vraag en aanbod moeten tegelijkertijd ontwikkeld worden en elke ontwikkelaar van nieuwe technologie weet dat dat veel inspanning kost. Het is overigens een bijzonder mysterie dat áls het eenmaal gelukt is om vraag en aanbod tegelijk te maken, zoiets niet geweten wordt aan de inspanning van de ontwikkelaar maar de vraag. De vraag was er niet maar misschien toch ook wel, maar zo dat je het niet ziet. Latente vraag, zegt de marketing. Geschiedvervalsing, zegt de sociaalwetenschapper.

Ook opvallend in de dynamiek van ruimtetoerisme is de kracht van verbeelding en fantasie. Zoals ooit de droom van vliegen een hele bedrijfstak heeft voortgebracht, zo is nu de droom aan zet om aan de aarde te ontsnappen. Technologie wordt gedreven door de toekomst, de verbeelding van de volgende stap, door het 'nog niet'. Een algemene karakteristiek van nieuwe technologie is dat het zaken betreft die er nu niet zijn. Nu 'nog' niet zijn, zoals betrokken het dan noemen, waarmee direct de urgentie wordt gecreëerd dat ze er zullen zijn of zouden moeten zijn. Maar in feite zijn het zaken die er gewoon niet zijn. Innovatieonderzoekers zijn specialisten in zaken die niet bestaan, zo leg ik het wel eens mijn studenten uit.

Gekoppeld hieraan is de krachtige rol van voorspellingen. Zoals de Maastrichtse filosoof Rein de Wilde (2000) ooit heeft laten zien, zitten voorspellers altijd vooraan bij nieuwe technologie. Ze zitten vooraan en ze zitten ernaast. Kijk eens naar de studie uit 1996 dat ik al noemde. Die voorspellingen zijn niet uitgekomen. Maar de verbeeldingsmachine gaat evengoed door. In een rapport van de Federal Aviation Administration uit 2010 wordt gemeld (FAA 2010, p.7): "market studies have shown that "space tourism," whereby customers pay a fee to experience suborbital 
spaceflight, could become a billion-dollar market within 20 years." Hierbij wordt verwezen naar een studie van 2006, van vier jaar eerder, met een grafiek die ten tijde van het FAA rapport al niet meer geldig was (p.8). Wat het geval van ruimtetoerisme ook laat zien is hoe met zulke voorspellingen een race van start gaat om de voorspelde toekomstige miljarden te kunnen incasseren, waarbij partijen elkaars stappen nauw in de gaten houden. Voorspellingen zijn dus niet onschuldig, ze zijn sturend onderdeel van het spel waarin nieuwe technologie vorm krijgt. Voorspellingen doen iets, ze zijn performatief zoals ik en anderen hebben benadrukt in eerder onderzoek, dat bekend geworden is als de sociologie van verwachtingen (Van Lente 2012).

\section{Duurzaamheid en behoefte}

Ruimtetoerisme toont ook de betekenis van behoefte bij innovatie en de samenhang met duurzaamheid. In mijn vorige oratie, vijf jaar geleden, heb ik de dynamiek geschetst van behoefte en innovatie (Van Lente, 2010). Mijn conclusie was dat behoefte niet aan het begin staat van een ontwikkeling, zoals het romantische beeld van techniek dat wil, maar aan het eind. Behoeften zijn niet gegeven, maar gemaakt. Mijn punt was ook dat een behoefte niet een uitdrukking is van een unieke individueel verlangen, maar een uitdrukking is van hoe de maatschappij georganiseerd is. De voorbeelden van watervoorziening in Parijs rond 1800 , fotografie rond 1900 en Internet rond 2000 laten zien dat behoeften mee veranderen met technische ontwikkeling. Deze zomer is Europa opgeschrikt door grote vluchtelingenstromen, die grote afstanden naar en in Europa afleggen. Wat is, volgens een reportage van het dagblad Trouw de basisbehoefte van deze vluchtelingen? Een smartphone. Ga maar na, via smartphones is er contact met familie verder op de route is, is er informatie over de beste plaatsen voor grensovergangen en kan er geld overgemaakt worden. Bij grensovergangen bieden providers worden gratis simkaartjes aan. (Trouw, 14 augustus 2015). 
Mijn stelling vijf jaar geleden was dat we behoeften in ontwikkeling kunnen zien en mijn voorbeeld was de iPad. Vijf jaar geleden was het onduidelijk wat je ermee zou moeten doen, maar het was al wel te herkennen als iets waar we behoefte aan zouden gaan krijgen. En inderdaad de behoefte aan iPads en andere tablets is zich aan het nestelen. Werknemers van de Universiteit Maastricht krijgen een tablet, er zijn iPad scholen opgericht en er wordt gemopperd dat zware studieboeken voor brugklassers toch echt niet meer van deze tijd zijn. Enzovoorts. Enzovoorts.

Ruimtetoerisme, zo is mijn stelling, is een behoefte in wording. Nu komt het de meesten van ons nog buitensporig voor, iets voor een dwaze miljardair die uit gebrek aan fantasie over hoe het geld op aarde te spenderen dan maar de ruimte ingaat. Toch is het heel goed denkbaar het een normale bezigheid wordt, iets wat hoog op wensenlijstjes staat. Het is zelfs goed denkbaar dat het uiteindelijk onrechtvaardig wordt om anderen deze mogelijkheid te ontzeggen. Stelt u zich eens voor. Over twintig jaar is ruimtetoerisme een perfect eindexamencadeau. De gedachte is dan bijvoorbeeld dat het hoort bij je opvoeding dat je tenminste éénmaal de blauwe wereld in al zijn kwetsbaarheid hebt kunnen zien - een unieke ervaring en het maakt je een betere wereldburger. Het is een mooie huwelijksreis: in plaats van samen romantisch naar de maan kijken, samen naar de wereldbol kijken. En, om de speculatie maar even voort te zetten, het is een perfect geschenk voor een pasbenoemde hoogleraar die net zijn inaugurele rede heeft gehouden - de doos voor enveloppen staat bij de uitgang.

Als iets zich eenmaal genesteld heeft als behoefte is het zeer moeilijk weg te nemen. In een liberale maatschappij gaan we elkaar niet betuttelen over de keuzes die we maken. Jij jouw behoefte, ik de mijne. Deze onmacht om nieuwe behoeften weer weg te krijgen wordt versterkt wanneer een behoefte promoveert tot recht of zelfs verplichting. Een behoefte is niet iets dat in je hoofd zit, of in je hart, of in je onderbuik, het is geen anatomisch attribuut. Een behoefte is 
een uitdrukking van hoe het dagelijks leven nu kennelijk in elkaar zit. Vorig jaar besliste een rechter in Duitsland dat de failliete beklaagde weliswaar enorme schulden heeft maar niet afgesloten mocht worden van internet, net zomin als van gas of elektriciteit. Internet, zo redeneerde de rechter, is een recht omdat het voor het sociaal functioneren noodzakelijk is. Wintersport was ooit exotisch en buitenissig voor Nederlanders, iets wat alleen de zeer rijken konden verlangen en de rest kon er zich niet veel bij voorstellen. Wintersport is gedemocratiseerd. Ik heb een poos gewerkt bij het grote adviesbedrijf KPMG gewerkt. Eén van de standaardvragen van collega's onderling zo rond februari was "Ben je al op wintersport geweest of moet je nog?" Wintersport was toen al lang geen verse behoefte meer of een pas verworven recht, maar een verplichting. Ben je al in de ruimte geweest, of moet je nog?

Deze behoeftendynamiek is problematisch. Het eerste probleem is het democratisch tekort: als behoeften zich ontwikkelen zou je daar ook inspraak in willen. Tien jaar geleden had ik geen behoefte aan een iPad en nu wel. Niemand heeft mij ooit gevraagd of ik deze behoefte wel wil. Ik heb geen inspraak gehad en ik zou zeggen, net als vijf jaar geleden: baas in eigen behoefte!

Het tweede probleem is onduurzaamheid. Het is erg onhandig dat de behoefte aan automobiliteit zo geworteld is. En dat is niet zomaar terug te draaien, net zomin als Internet, waarvan de energieconsumptie steeds grotere vormen aanneemt. Britse onderzoekers waarschuwen dat het nu al $5 \%$ van het energiegebruik betreft en dat het elke 4 jaar verdubbelt. Dat betekent dat het energieverbruik van Internet in 2030 net zoveel zijn als de mondiale energieconsumptie nu (Farmer, 2015). Ruimtetoerisme als behoefte zou dramatisch zijn vanuit het oogpunt van duurzaamheid. De hoeveelheid brandstof die nodig is om aan de atmosfeer te ontsnappen is immens en de uitstoot op grote hoogte in de atmosfeer draagt onevenredig meer bij aan het broeikaseffect, aan vervuiling en aan afbraak van de ozonlaag. Volgens een studie uit 2010 in Nature is het effect 
van 1000 suborbitale vluchten, dus even naar $100 \mathrm{~km}$ hoogte en weer terug, een verhoging van de gemiddelde temperatuur op aarde van een halve graad Celcius. Het is uiteraard met veel onzekerheid omgeven, maar het laat zich raden wat de effecten zullen zijn wanneer de ruimtevaart bereikbaar is geworden voor, zeg, de top $1 \%$ van inkomens, of de top $10 \%$. Of de zeven miljard waar Richard Branson het over had.

De vraag is niet of een behoefte echt is of gemaakt, op de keper beschouwd zijn alle behoeften gemaakt. De vraag is welke behoeften we moeten gaan maken. De vraag is welke behoeften we ons kunnen veroorloven. En ik zou willen beweren dat een behoefte aan ruimtetoerisme daar niet bij hoort. Dat betekent dat als STS deze ontwikkeling bestudeert, het niet voldoende is om het krachtenspel in kaart te brengen en daar verslag van te doen. Ook moet zichtbaar gemaakt worden welke verbeelding gemobiliseerd en versterkt wordt, die van vooruitgang en heldendom, of van duurzaamheid en zorg. En welke gevolgen heeft zo'n verbeelding? En is dat een goede ontwikkeling, vanuit welk perspectief?

\section{Metafoor}

Het geval van ruimtetoerisme laat zien hoe ik de komende jaren vanuit STS wil werken aan vragen over technologie en toekomst. Het zijn innovatievragen over de dynamiek van opkomende technologie en culturele vragen over verbeelding, collectieve ambitie en collectieve creatie van behoeften.

Ik zou $u$ nu even verder willen meevoeren in deze STSmanier om naar de wereld te kijken en ik wil dat doen aan de hand van de metafoor toerist. Toerisme als metafoor van het vakgebied van wetenschap- en techniekonderzoek, STS. Zygmunt Bauman, die deze metafoor op een fraaie manier gebruikt om de huidige postmoderne tijd te typeren (Bauman 2002), moet me maar vergeven dat ik onze toerist 
eventjes op een andere en lossere manier inzet - maar ik denk dat het verhelderend is voor mijn doel (Lakoff e.a. 1980).

Het onderzoeksgebied Science and Technology Studies richt zich op het onderzoeken en begrijpen en kritisch volgen van wetenschappelijke en technologische ontwikkelingen. De centrale boodschap is dat wetenschappelijke feiten en technologische resultaten intrinsieke aspecten zijn van maatschappij en cultuur en niet van buiten op ons afkomen. Wetenschap en technologie zijn zowel een uitdrukking als een medevormgever van maatschappelijke verandering, zoveel heeft een halve eeuw van onderzoek wel duidelijk gemaakt (Bijker 1995). STS is daarnaast een perspectief dat anders en dwars is. Het is een uitnodiging om bij alles, ook bij wat zich als massief en onontkoombaar voordoet, voor te stellen dat het ook anders had kunnen zijn. It Could Be Otherwise (ICBO), zoals Steve Woolgar (2014) dat vorig jaar in een lezing in Maastricht samenvatte. Het is een uitnodiging om je voor te stellen dat er niets zomaar is, de regels, de dingen maar ook de feiten die zich met een vanzelfsprekend aplomb laten gelden. Niets is nu eenmaal zo, het is gemaakt en die ontstaansgeschiedenis is te onderzoeken. De methode van STS is om het werk te volgen dat nodig is om zaken te laten zijn zoals ze zijn en zich aan ons voordoen. Wat doet een wetenschapper die de vervuiling van ruimtevluchten berekent, wat doet een ondernemer als Branson met visionaire plannen, een journalist die hem van hovaardij beticht? Wat doet een politicus die ook mee de ruimte ingaat, wat doet een ruimtevoertuig dat bewezen is maar toch ontploft, wat doet het gerapporteerde feit dat mensen voor $\$ 50.000$ de ruimte in willen? Hoe krijgen deze mensen, dingen en feiten voor elkaar wat ze doen? Welke lijnen worden bij elkaar gebracht, welke netwerken worden gemobiliseerd? Deze STS-methode heeft veel onzichtbaar werk aan het licht gebracht, van netwerkbouwer tot gebruiker, van parlementslid tot institutie, van elektron tot huisvrouw. 
Om dit dwarse perspectief en deze ontregelende methode te kunnen volgen is de STS-er noodzakelijkerwijs een bezoeker van werelden: de wereld van technisch onderzoek, de wereld van commerciële bedrijvigheid, van gebruikers, van beleidsmakers, van technische systemen, van media. Karakteristiek voor wetenschappelijke en technische ontwikkelingen is dat de krachtenvelden uit al vele werelden bij elkaar komen op ingewikkelde en ondoorzichtige wijze. Het blijft ook ondoorzichtig omdat men doorgaans binnen één wereld blijft. Juist omdat de STS-er wel die verschillende werelden bezoekt is er iets nieuws te melden. De STS-er kan nieuwe vragen stellen, patronen herkennen, dynamieken zichtbaar maken - niet omdat de STS-er slimmer is, of gevoeliger dan de reguliere bewoners van de werelden, maar omdat een STS-er de atmosfeer van de bekende werelden kan verlaten. De STS-er als toerist, of, zo u wilt, als ruimtetoerist. Niet de toerist die gemakzuchtig de sjabloon volgt van de 'tourist gaze', zoals ik dat in het begin schetste, maar de eigenwijze toerist die actief observeert, experimenteert en vergelijkt. STS laat zien wat er gaande is, hoe verlangens en ambities naar boven komen en zich vastzetten in cultuur en instituties.

De STS-er als toerist van werelden zal die werelden ook verstoren en veranderen - en moet dat ook doen. STS moet geen l'art pour l'art zijn, of in de termen van mijn nieuwe faculteit, l'art et culture pour l'art et culture. Er is verstoring en verandering door de nieuwe blik, door woorden en argumenten, een taal die anders en onverwacht is. STS heeft instrumenten ontwikkeld om betrokkenen een blik op hun eigen wereld te geven, vanuit de ruimte als het ware. Diverse aanpakken voor vragen van technologie en toekomst zijn inmiddels beschikbaar en worden op vele plaatsen benut. Een voorbeeld is Technology Assessment in al zijn varianten, waarbij een bredere groep actoren en factoren aan de orde komt. Andere voorbeelden zijn scenario workshops of vignette studies, waarin mogelijke toekomsten worden ondervraagd. 
De verstoring van STS heeft een emanciperend en democratiserend effect. Wanneer immers de krachtenvelden van de werelden geschetst worden, wordt ook zichtbaar welke partijen daarin minder krachtig zijn of het onderspit delven. Wanneer je laat zien dat het anders kan, komt al snel de vraag op of het anders zou moeten. Van it could be otherwise naar should it be otherwise? De traditionele strategie van STS om te verstoren en te veranderen is om stem te geven aan alle stakeholders, ook de niet-dominante partijen, om de stemmen en perspectieven die niet gehoord zijn toch hoorbaar en zichtbaar te maken. Een belangrijk traditie in STS, bijvoorbeeld, is het zichtbaar maken en versterken van de rol van gebruikers (Oudshoorn en Pinch, 2003). Wanneer gebruikers betrokken worden bij technische ontwikkeling, zo is de gedachte, leidt dit tot maatschappelijk betere technologie (van den Hoven e.a. 2014). Dit te benoemen is emanciperend en het bieden van taal en instrumenten is democratiserend.

De rol van STS als de toerist die ziet dat het anders zou kunnen zijn en daarmee emancipatie, democratie en de rol van gebruikers versterkt, is belangrijk, maar ik wil daar toch een kanttekening bij plaatsen. Soms is het niet genoeg. Het geval van ruimtetoerisme met de krachtige verbeeldingen en het gevaar van de ontluikende behoefte laat dat goed zien. Het probleem is immers dat de gebruikers en andere stakeholders zelf ook onderdeel zijn van de dynamiek die het probleem vormt, zeker als gebruikers worden benaderd als potentiële consumenten. Het is niet voldoende om tevreden te zijn wanneer alle stakeholders of gebruikers tevreden zijn omdat het dan nog steeds mogelijk dat de ontwikkeling een verkeerde kant opgaat. $\mathrm{Er}$ is meer nodig dan emancipatie en democratisering. $\mathrm{Er}$ is meer nodig dan het volgen van zelfverklaarde behoeften van gebruikers. Ik heb eerder de term zelfopvoeding gebruikt: zoals we tot ons $18 \mathrm{e}$ worden opgevoed en leren dat niet al onze verlangens legitieme behoeften zijn, zo zou er ook een maatschappelijke plaats moeten zijn om behoeften kritisch te bevragen (Van Lente, 2013). Zelfopvoeding zie ik als een geïnstitutionaliseerd collectief leerproces rond de vraag hoe we nieuwe 
technologie als het vervullen van een behoefte zien. Nogmaals, een behoefte zit niet in het hoofd, maar in de organisatie van het dagelijks leven. De vraag is dus hoe we het dagelijks leven zouden willen organiseren, inclusief alle techniek, regels, verwachtingen en behoeften die daarbij horen. Dat vraagt reflexiviteit, bewustwording van wat er gaande is en gerichtheid op leren. Dat vraagt ook om het besef dat wat we nu als waar en legitiem ervaren misschien niet waar en legitiem is. Het vraagt om afstand te nemen van onze wereld met onze verlangens, onze behoeften en onze zekerheden, en als ruimtetoerist te vragen: should it be otherwise?

\section{Dankwoord}

Tot slot enkele korte woorden van dank. Het zal ontoereikend zijn want ook bij wetenschap geldt dat het geen individuele maar een collectieve prestatie is. Ik heb aan veel mensen veel te danken, teveel om op te noemen.

Maar toch, in de eerste plaats, dank aan het College van Bestuur dat nadrukkelijk het interdisciplinaire karakter van de universiteit en de faculteit steunt. De universiteit van Maastricht wil anders zijn, en is ook anders, met de nadruk op onderwijsvernieuwing en de nadruk op interdisciplinariteit. Deze nadruk maakt deze universiteit een ideale plek voor STS als de toerist.

Dank ook aan mijn collega's bij de Faculteit Cultuur- en Maatschappijwetenschappen die mij in het afgelopen jaar zo snel en hartelijk hebben opgenomen. Rein, Wiebe, Karin, Anique, Valentina, Sabine, Tsjalling, Sophie, Renee, Georgi, Kiran, en alle anderen, jullie waren er snel bij om met mij lief en leed te delen. Ik kan concluderen dat de locatie van STS in deze faculteit ook ideaal is. Het appèl van zelfopvoeding dat ik voor STS heb geschetst vraagt om inbreng van alle disciplines in de faculteit. Ik zie uit naar een intensieve samenwerking. 
Veel dank ook voor mijn vroegere collega's uit Utrecht en bij ICIS, in het bijzonder mijn promovendi, dank voor alles wat ik van jullie geleerd heb. Dankzij jullie kan ik hier nu verder gaan - en het zal niet zonder jullie zijn, we zullen elkaar nog veel treffen.

De capaciteitsgroep Technology and Society Studies en vooral Wiebe Bijker dank ik voor het gracieuze vertrouwen in het overnemen van taken. Wiebe, jij hebt het in de afgelopen 20 jaar voor elkaar gekregen om de grootste concentratie van STS-onderzoek in Nederland te verzamelen en te inspireren en het een eigen Maastrichts stempel te geven. Je vertelde me dat het de grootste STS-groep in Europa is, misschien wel van de wereld. In het kader van deze oratie kan ik daaraan toevoegen: misschien wel de grootste van het heelal!

Nelly, familie, vrienden, heerlijk dat jullie er bij zijn. Dankzij jullie ben ik wie ik ben, dankzij jullie kan ik dit grote project aangaan. Lieve Jowan en Carina, vijf jaar geleden als voorzichtige pubers aanwezig en nu uitgevlogen naar wereldreis en het moederschap. Saskia, we hebben al zoveel gedeeld de afgelopen 25 jaar en ik heb zoveel aan je te danken. Ik ben tot tranen geroerd dat we samen aan een nieuwe fase in ons leven beginnen, in Maastricht. Misschien als emigranten, misschien als toeristen, in ieder geval met ruimte voor de toekomst.

Ik heb gezegd. 


\section{Literatuur}

Abitzsch, S. (1996), Prospects of Space Tourism, study presented at the 9th European Aerospace Congress, May 15, Berlin.

Bauman, Z. (2000), Liquid Modernity, Cambridge: Polity

Bauman, Z. (2002), Society under Siege, Cambridge: Polity

Beck, U, Giddens, A. and Lash, S. (1994). Reflexive modernization: politics, tradition and aesthetics in the modern social order. Cambridge: Polity Press.

Bijker, W.E. (1995), Of bicycles, bakelites, and bulbs: toward a theory of sociotechnical change, Cambridge, MA: MIT Press

Bolton, A. de (2002), The Art of Travel, London: Hamish Hamilton.

Brown, N., Rapport, B., \& Webster, A. (2000), Contested futures: a sociology of prospective techno-science, Aldershot: Ashgate Press.

Farmer, B. (2015), Internet 'rationing' needed as UK cannot keep up with demand, The Telegraph, 3 May.

Federal Aviation Administration (2010), The Economic Impact of Commercial Space Transportation on the U. S Economy in 2009, Washington: FAA report DTFAWA-10-D00027.

Franklin (2003), The Tourist Syndrome - an interview with Zygmunt Bauman, Tourist Studies, Vol 3(2), 205-217.

Hoven, J. van den, Doorn, N., Swierstra, T., Koops, B.-J., Romijn, H. (Eds.)(2014), Responsible Innovation: Innovative Solutions for Global Issues, Dordrecht: Springer 
Kluger, J. (2014), Enough With Amateur-Hour Space Flight, Time Magazine, October 31.

Lakoff, G. and M. Johnson (1980), Metaphors we live by, Chicago: University of Chicago Press.

Lente, H. van (2010), De maakbare behoefte: naar een filosofie van duurzame ontwikkeling, Maastricht: Datawyse. Oratie Universiteit Maastricht.

Lente, H. van (2013), Humanisme en de ongemakkelijke vragen van duurzaamheid, Journal of Humanistic Studies/Waardenwerk, No. 52, 71-79.

Lente, H. van (2012), Navigating Foresight in a Sea of Expectations: Lessons from the Sociology of Expectations, Technology Analysis \& Strategic Management, Vol. 24(8), 789-802.

Oudshoorn, N. en T Pinch (2003), How users matter: the coconstruction of users and technology, Cambridge: the MIT Press

Mann, A. (2010), Space tourism to accelerate climate change, Nature (October 22).

Seedhouse, E. (2008), Tourists in Space: a Practical Guide, Heidelberg: Springer.

Urry, J. (1990), The Tourist Gaze, London: Sage

Verhovek, S.H. (2014), Not a Flight of Fancy, New York Times 4 November

Wilde, R. de (2000), De voorspellers: Een kritiek op de toekomst-industrie, Amsterdam: De Balie.

Woolgar, S. (2014), It Could Be Otherwise, MUSTS lezing Universiteit Maastricht, 10 december. 